\title{
Historiographycal Review of Scientific Researches on the Problem of People's Perception of Climate Change
}

\author{
Ksenia V. Reznikova* and Yulia S. Zamaraeva \\ Siberian Federal University \\ 79 Svobodny, Krasnoyarsk, 660041, Russia
}

Received 14.07.2017, received in revised form 17.08.2017, accepted 24.08.2017

The topic of people's attitude to climate change is quite new, since it has emerged just in the latter half of the 20th century. In the foreign science this problem was raised in the 1990s, while yet the Russian scientists have not paid enough attention to it. In the 1990s the foreign researchers analyzed the attitude to climate change in Germany, the UK, Uruguay, the USA and in other countries. These scientific works are characterized by quite a general nature. The 2010s abroad are marked by a scientific boom related to the consideration of the attitude to climate change; interestingly, these researches are very specific and narrow that is explained through the choice of subjects, respondents and etc.

Keywords: global climate warming, population's attitude, climate change historiography.

The study has been supported by the Russian Foundation for Basic Research, the Government of the Krasnoyarsk Territory, the Krasnoyarsk Regional Science and Technology Support Fund to the research project № 17-16-24601.

DOI: 10.17516/1997-1370-0144.

Research area: culturology.

At different times, global climate changes on the Earth have taken place, and yet, they have been adequately explored by the sciences. Still, all the previous climate changes happened before the time of humans and without their power. For this reason, the question of people's attitude towards climate change is quite a new one - it appeared just in the later $20^{\text {th }}$ century. This article contains an observation on national and foreign publications of almost the last 70 years - from 1950 to 2017 - revealing the attitude toward the climate change. The work starts with an annalistic review on scientific researches dedicated to the attitude to the climate change. Each time period (five in total) includes reviews of foreign and domestic researches.

\section{Researches on the attitude to the climate change in the 1950s-1960s}

Among the foreign scientific publications of the 1950s-1960s none of them are dedicated to climate change that proves the fact that there was

(C) Siberian Federal University. All rights reserved

* Corresponding author E-mail address: axu-ta@mail.ru 
not so much tension around this issue in the postwar time and at the Cold-War start.

The national researches are primarily dedicated to the question of agricultural development and effectiveness in different Soviet territories, to the fauna ecology and geographic environmental identity. The subject field excludes the problem of climate change.

\section{Researches on the attitude to the climate change in the 1970s-1980s}

The foreign researches of the 1970s-1980s mainly address the problem of climate change in four areas: 1) studies on the climate change origin: increased $\mathrm{CO}_{2}$ (Manabe, 1980; Augustsson, 1977; Wang, 1980), calcium carbonate (Damuth, 1975), solar radiation flux (Coakle, 1979), water ice growth (Semtner, 1976) and internal and external reasons for the climate change (Robock, 1978); 2) expertise assessment of possible climate scenarios (Climate Change to the Year 2000; A Survey of Expert Opinion, 1978), climate modelling via physical patterns and mathematic systems (Schneider, 1974; North, 1975; North, 1979; Allison, 1977); 3) exploration of global climate change (North, 1975; Cess - Tellus, 1975; Eddy, 1977) in the Central, Southern, Eastern (Warrick, 1980; Charney, 1977; Leith, 1975) and Northern countries abroad (Kent, 1971; Stockton, 1979); 4) problems of anthropogenic climate change (Sagan, 1979; Powell, 1970).

In the 1970s-1980s the Russian researchers did not pay attention to the attitude to climate change, yet quite extensively investigated the change as such, both in local - within the impact of certain cities or water bodies on the environment (Vendrov et al., 1970, Vorontsov, Khayrullin, 1977; Martazin 1970) or within the climate impact on certain albeit major entities (Heifetz, 1979, Miagkov, 1981) - and international scales Stenchikov, Stepanov, 1989;
Kuvshinova, 1987; Kagan et al., 1984; Chubukov, Shvareva, 1973; Smirnov, 1975).

\section{Researches on the attitude} to the climate change in the 1990s

Among the pioneers who studied the attitude to climate change in 1990s there were P.A. Andersen, M.W. Lustig and J.F. Andersen (Andersen et al., 1990). Although in the 90s much emphasis is still put not on the attitude towards the climate change, but to the change per se and its impact on different areas of the human life. For example, L. Westra addresses not the attitude to global climate, but interrelations between the ecology, ecosystems integrity and human health, in particularly, considering climate change and global warming as the problem areas (Westra, 1996). The author naively enough assumes that the main principle which will ensure a holistic perspective is the good faith principle, and not, for example, an externally-supported approach of rules and binding restrictions.

L.E. González and P. Da Silveira carried out their research on the attitude to the global environmental problems, in particular, to climate change, in Uruguay (González, Silveira, 1997). The research consists of three basic modules: climate and environmental changes most felt by the respondents; the main sources of information about the ecology and climate; the assessment of individual performance against climate and environmental change. L.E. González и Р. Da Silveira suggest that establishing a dialog with the society is more important than assessing the accuracy of public views. The work demonstrates that the respondents much appreciate radio and television as the sources of information about the climate changes, at the same time, educational institutions also develop as a reporting channel.

The public perception of global warming is analyzed by R.J. Bord, A. Fisher and R.E. O'Connor who synthesize the global 
warming research data carried out in the USA and internationally (Bord et al., 1999). The researchers were interested in the following aspects of the attitude to global warming: the awareness level, potential risk evaluation, willingness to pay or contribute to mitigate negative effects caused by global warming or to adapt to them. The authors concluded that the respondents do not understand the global warming phenomenon correctly willing to contribute combating global warming only on a limited scale. As R.J. Bord, A. Fisher и R.E. O'Connor explaine, despite the international concern about global warming it was not an "overriding issue".

In the 1990s there is a launch of cross-cultural researches on the attitude toward climate change; for example, E. Darier and R. Schule study the attitude of German and UK non-governmental organizations (in Frankfurt and Manchester, correspondingly) to global climate change and to possible measures to be taken and find out quite a strong resemblance of these public perceptions in both cities (Darier, Schule, 1999).

There are no national researches on the attitude to climate change in the 1990s-2000s. Yet, within the same period the Russian analysts take a shot on theoretical and methodological reflection over such foreign and national climate programs as the Club of Rome's methods (1968), United Nations Conference on Environment and Development (Rio de Janeiro, 1992), International Geographical Union Conference on "Global Changes and Geography" (Moscow, 1995). By analyzing the Club of Rome's activity, system researches on global changes by T. Malthus, J. Forrester (WORLD 2), Dennis and Donella Meadows (WOLD 3), S.V. Dubovsky develops a guideline for the global modeling and claims the analysis of biosphere issues through the climate model and global biogeochemical cycles to be one of the main challenges for the global researches
(Dubovsky, 1998). He suggests two scenarios for the biosphere processes and anthropogenic activity: global climate warming and nuclear winter onset. To prevent this will require the global development paradigm revolution: a switch from the global growth trend to a "zero growth" (i.e. the development with permanent macro indicators), transformation of the universal ideas, and a new system of international relations, education, ethics and morality. V.V. Annenkov tries to describe geographical approaches towards global changes on the basis of V.I. Vernandskii's noosphere conception and a group study by the Russian and American geographers "Global Change: Geographical Approach" (Annenkov, 1996).

In $1992 \mathrm{ACPOR}^{1}$ (rus. - VCIOM) reported on the results of the All-Union survey (November, 1989; April and August, 1990) on mass ecologic perception obtained through the methods by B.Z. Doktorov, V.V. Safronov and B.M. Firsov. The public opinion poll indicated that $90 \%$ of respondents worried about the environmental deterioration (on the $5^{\text {th }}$ out of 12 severe problems disturbing the society). The respondents expressed their willingness to meet environmental challenges, though the degree of this willingness is related to the residence country's sustainability. In most cases people build their environmental consciousness by themselves relying on their own observations (47 $\%$, their friends, acquaintances and relatives' opinions (41 \%); on articles and journalists' speeches (27\%), scientific reports (17\%), and finally - on informal groups' performance and environmentalists' activity (9\%). The researchers conclude that within the ecologic thinking formation the knowledge should prevail over stereotypes. One of desirable objectives for the future should be ecologization of the mass and professional consciousness through the analysis of possible impact, minimization of a potential 
damage and embracement of a sound judgment if some unintended consequences emerge.

\section{Researches on the attitude to the climate change in $2000 \mathrm{~s}$}

The foreign researches of the 2000s-2010s can be broadly classified into two unequal periods: from 2000 to 2003 for theoretical reflection over the problem of climate change in the history, ecology, social studies and sociology; from 2004 - consideration over the public opinion on climate changes.

In $2000 \mathrm{R}$. Wilson investigates three crucial ecologic problems which dominate in the public opinion: the air pollution impact on the human health, carbon emissions in the atmosphere and environmental contamination of the water supply systems. The author finds that the human race is able to get involved into disaster prevention processes (Black Death, All-Out Nuclear War) quite actively. B. Messerli, M. Grosjean, T. Hofer, L. Núñez, C. Pfister keep an eye on three large periods of fundamental changes in the humannature relations throughout the whole history: the Holocene (predominance of the nature, human migration and adaptation to the environment); agrarian society and transformation from the need to survive to innovative performance (first climate changes and first protective technologies to resist extreme climatic conditions); the third, modern, period of frequent and short climate changes. The scientists predict a need for biophysical researches integrating with the analysis of how people impact the natural resources. In 2002 the scientists investigate general questions of the climate-society relations and a need to obtain some reliable information about climate changes to be applied to take measures (Liverman, Merideth, 2002).

In 2004 due to media publication of the Kyoto protocol, there is an emerging body of studies on the public attitude toward climate change
(Plotnikoff et al., 2004). In Alberta, Canada, 600 households have been interviewed on phone. The survey reveals the most burning issues: health problems, air pollution, and poor awareness of the population about the environment protection. The researchers assume that the environmental problems emerge in the residents' consciousness only within their domestic space (energy saving, eco-transport, etc.), and consequently, they recommend the mass media and the health care sector working with the cross-industry groups to preserve environmental soundness.

In 2006 I. Lorenzoni and N.F. Pidgeon consider public views on climate change in Europe and the USA and give some data that the majority of people are aware of the problem of climate changes, given their personal experience, knowledge, balance of costs and benefits and loyalty to other social actors. To establish peoples' confidence in the information about climate change, it is firstly necessary to discuss the scientific advances, and secondly to carry out permanent discourses on climate changes.

In 2007 C.A. Shisanya and M. Khayesi conduct a poll among 132 respondents in Nairobi (Kenya) to find out whether they understand the ecological problems and threats. According to the results, the respondents do not consider the climate changes as a serious problem in Nairobi, in parallel to evident poverty, unemployment, lack of crime prevention and limited availability for education. The authors assume that the problem of attitude to climate change should be addressed in economically developed countries and the Kyoto Protocol should be also decided on.

In 2008 there is a research which deals with the people's attitude to climate change and providing guidance for the state policy on environmental awareness among the world's population. R. Shwom, A. Dan and T. Dietz represent public bodies as key actors in the information influence on the world community's 
environmental awareness and recommend: a high publicity of extreme environmental events for the population (floods, forest fires, hurricanes, droughts, water shortage and etc.). Similar recommendation is proposed by S.C. Moser and A.L. Luers: the need to involve resource managers for the people of California to adjust successfully to constant climate changes through the analysis of potential risks, awareness activities on climate changes and etc. The scientists believe that the resource managers can become an important force in the context of discussion on possible solutions and climate risks management at the government level. L. Whitmarsh is interested in the climate effect on the human's health and life as a threat for the present and future and demonstrates the results of her own investigation carried out through the interviews and surveys among the residents of Southern England. Judging by the results, the researcher concludes that the residents do not perceive the current climate change (flood, for example) as a personal threat, but respond and change their behavior (to take certain measures) after these changes. In this regard the author suggests formulating a political strategy on the community involvement into climate changes. J. Fenger, E. Buch, P.R. Jakobsen, P. Vestergaard analyze the Danes' opinions and reactions to the risk of the sea-level rise and possible changes in economy, sociology and biology (Fenger et al., 2008).

2009 is marked by the researches related to the Western and Russian Arctic (Forbes, Stammler, 2009) as well as to the integration of science and experience of the indigenous people of the North to understand the climate change process (Informing Decisions in a Changing Climate, 2009). The work by E. Moyano, A. Paniagua and R. Lafuente describes environmental sociology as a field of public opinion and environmental policy studies. When considering the public opinion it is important to bear in mind the scale of social perceptions of the environment at the following levels: local, regional, national and international. This scale was developed through the annual public opinion poll in the Spanish Institute of Astrophysics of Andalusia (in 2001 2009). The results consistently demonstrate the view of Andalusia's residents about optionality of the issues of climate changes in the local and regional solution strategy, since no action there could resolve the global environmental problem.

In 2010, a ranking assessment of the community's choices for potential ecological consequences is carried out using the paircomparison method (Williamson, Watson, 2010). The ranking consists of 8 hypothetical consequences caused by climate change. The respondents involved the adult population, characterized by different educational levels and living in cities and non-urban clusters. Among the most acute problems they mentioned climate change impact on the water and fish and forest eco-systems (including wild animals). Gender differences in the answers were emerged in the problems ranking: while women put the problem of climate change impact on the wild animals first, men place a priority on the impact on rest. The thing which united the respondents was their choice of eco-goods and services. S.R. Weart in his research on anthropogenic global climate change in the $20^{\text {th }}$ century proves the idea that the global warming phenomenon was known back in 1896, recalling the evidence that burning fossilfuel carbon dioxide can slowly heat the whole planet. In the mid $20^{\text {th }}$ century this idea was brought sharply into focus of chemical pollution, nuclear armament and human activity growth. In the latter half of the $20^{\text {th }}$ century these problems gained more increased attention from the policy, international relations and transformation of moral norms. In 1970s there is a scientific consensus on the discussion over transitional period to a new millennium. The mass media are charged 
to broadcast the environmental problem and to gain the international attention on the safety risks and necessity to take steps. Investigating carbon emissions into the environment L. Whitmars and J. Köhler believe that the science should focus on conducting multidisciplinary researches on psychological, cultural and infrastructural factors, and assume that the environment can be improved by the low-carbon automobile industry and change in the way the transport users behave. F. Reusswig mentions the problems of growth in the industrial world of demand which causes an increasing pressure on the environment in the form of wastes and emissions. Decrease in the global mass advertisement of goods and consumption materials will help to protect the environment. L. Steg and C. Vlek consider the problem of climate change impact on the advanced economies; they also mark a need for food safety, migration, national security and integrated approach in meeting natural disasters.

Indeed, we have failed to find any researches on the attitude to climate change in the Russian science. The analysts are interested in considering climate change objectively, considering such researches as an internal part of the national strategy for Russia development (Kattsov, 2008); in the need for drastic measures from the government against climate change, particularly in the Northern territories (Tsalikov, 2009); in climate change fight within the context of oil lobby (Markov, 2008).

Some scientists concentrate on the analysis of basic international decisions related to the fight against global climate change made during the Conferences on Environment in Rio de Janeiro, Kyoto and Copenhagen and on the attitude towards these decision in different countries (Zalikhanov, 2003; Larin, 2005; Chelovek i klimat..., 2006; Izrael et al., 2002).
A.R. Kalinin,
O.S. Korobova
and

T.V. Mikhina (Kalinin, 2007) regard climate as a natural resource and as a public good, but do not touch upon the problem of the population's attitude to climate change. Maliarenko et al. does not consider either an objective picture of climate change, or the attitude, but calls for greater actions to enhance the human's adaptability to environmental changes (Maliarenko, 2009).

N.A. Vasilieva does not conduct any social researches on the attitude to climate change; her work is rather of a philosophic nature (Vasilieva, 2009). Considering that currently the mankind is under threat of a catastrophic future caused by rash and rapid technological development (one sign of an imminent disaster is climate change), N.A. Vasilieva urges to think about a noosphere scenario for the civilization's perspectives as the only possible future life.

\section{Researches on the attitude to the climate change after 2010}

After 2010 a good number of researches on the attitude to climate change have been conducted abroad. They cover all inhabited continents and interview quite narrow social groups; the research topics are usually quite specific.

Some researchers carry out their works in Africa, the most part of which suffers from the problem of water resources. E. Ojomo, M. Elliott, et al. analyze the experience on climate change and attitude to it in Nigeria where the need for freshwater resources is the most pressing (Ojomo et al., 2015). The authors address the students and university members as the respondents. The survey has shown that the vast majority of them think about the human's activity as the root cause for climate change. As it has turned out to be, the respondents are more aware about the climate change impact on the regional they live in, but not on the whole country. C. Ofoegbu, P.W. Chirwa, J. Francis and F.D. Babalola study the attitude to climate change in forest communities in Vhembe, 
South Africa, and find out that the respondents are poorly informed about climate change, though they have an idea about it; the respondents will responsibly treat the forests to fight against climate change (Ofoegbu et al., 2016). The authors sum up that it is necessary to educate local people about the causes and consequences of climate change, and to encourage their participation in the development of measures contributing to the climate change's consequences mitigation and adaptation to them.

The studies of attitude to climate change are still actively being continued in the USA. S.J. Carlton, A.S. Mase and others look into the impact of the last drought in the middle west of the USA on locals' beliefs about climate changes and related risks (Carlton et al., 2016). The researches compare the data of polls conducted in 2012 before the extreme drought and after and discover that the picture of climate change remains almost the same, though the risk perception has shifted, i.e. there is an expanded sense of drought risks and less concern about floods. Still, despite the changes in risks concerns, the researchers note that they are not so large enough to bring a common shift for more rational treatment of the environment. M.A. Ranney and D. Clark investigate what part of the USA's population understands the mechanism of global warming, and some of their experiments have demonstrated that almost none of American people are aware of it (Ranney, Clark, 2016). Although, briefing in physicochemical materials expands knowledge of the global warming mechanism among the respondents, so the authors draw a conclusion that it is necessary to increase general awareness of the population about climate, through, for example, the Internet, and not to hold a view of keeping the society informed about climate change is useless or even unproductive. N. Stenhouse, A. Harper et al. consider the conflict around the picture of global climate change in the
American Meteorological Society and assume that it undermines the scientific society's power to combat environmental problems (Stenhouse et al., 2017).

One of the most important social groups to study the attitude to climate change is represented by farmers whose activity is directly relied on the nature and depends on its state. K. Mohanraj and C. Karthikeyan analyze the attitude to climate change of the farmers in Tamil Nadu (Mohanraj, Karthikeyan, 2016). D.D. Poudet and T.W. Duex deal with the subject of water resource disappearance in Nepal connected with climate change and the analysis of the farmers' adaptation to it (Poudet, Duex, 2017). As the findings have indicated, 12, $2 \%$ of the water resources have dried up, 73, $2 \%$ become shallow over the last decade; that made the locals to take adaptation measures: to build water reservoirs, transport fresh water and dig deeper wells and etc. C. Galdies, A. Said et al. addressed climate change in Malta and what the farmers of Gozitana think about it, and thus have reached the following conclusions: there has been a shift in the climate sphere, which affects the weather conditions in the Maltese Islands; adaption measures for new climate conditions have been blocked by the absence of knowledge about how climate change can be influenced (Galdies et al., 2016). M. Eggers, M. Kayser and J. Isselstein analyze the attitude to climate change of German farmers working at pasturelands (Eggers et al., 2015). The research is based on the idea that apart from such factors as region, farm size, age and education, the most important one concerning climate change will be the farmers' socio-cultural background and their convictions. During the research, the authors have identified four types of economic managements depending on the awareness of climate change and preferable adaptation measures: profit optimisers, modernists, idealists and traditionalists. The first 
two of them have more rational convictions, the others are emotional ones. The optimisers and modernists also prove to be more prone to the adaptation measures.

Not less important group of respondents is teenagers and young people, since getting older they will face the most serious consequences of climate change; even now we need to know about their attitude toward this problem to take appropriate actions on information sharing. M.S. Prudente, J.C. Anito and S.E. Aguja analyze the knowledge and attitude of school students, their parents and teachers in the Philippines to climate change and find out that the students have only basic information about global warming and climate change, as well as that the level of knowledge about climate change varies depending on the respondents' residence (city, countryside or coast), that should be taken into account in sensitizing the population on environmental problems (Prudente et al., 2015). P.D. Nunn, K. Mulgrew et al. address a balance between spirituality and attitude to the nature among the students in the South Pacific Ocean Islands and discover that the respondent concern about climate change, and at the same time, they are characterized by the "space optimism" and environmental risk distancing - the ideas that "other places" are worse than their own environment (Nunn et al., 2016). Besides, the authors turn their attention to the importance of religion and spirituality in building their attitude to climate change and note that the information about climate change, rational use of the nature get better response if it is represented rather in the context of religion than in any social one. M. Morrison, R. Duncan and K. Parton (Morrison et al., 2015) consider the relation between religion and attitude to climate change not among the teens, but among the whole population in general. Using the web the authors interview 1927 Australians, practising four different religions (including
Christianity and Buddhism) and discover how these religious groups are different in their attitude to the following issues: climate change is related to the human's activity, efficiency of selfactions and need for policy interventions.

For some scientists the choice of respondents is quite a specific one and it highlights their pursuit to cover the widest range of opinions on climate change. Thus, J. Xiao, W. Fan et al. look into the experience and attitude to climate change in nurses, and how this knowledge is involved in the healthcare problems in China (Xiao et al., 2016). J.F. Luebke, S. Clayton (et al) make an assumption that the information about global climate change is comprehended in different ways by the communities, therefore, they conduct a survey in four countries of South America resulted in the fact that the population there is gravely concerned about the environmental problems and is keen to participate in pro-environmental behaviour in an active way (Luebke et al., 2015). Interestingly, the survey has been carried out among the zoo's visitors, whose social and emotional context has also been included in the response analysis.

The pursuit to a detailed examination of the world population's attitude to climate change is also proved by certain specific topics raised by the scientists. For example, by evaluating the share of visuality in the environmental news S. Rebich-Hespanha and R.E. Rice investigate the way how the information about global climate change is delivered to the population (RebichHespanha, Rice, 2016). J. Sohlberg analyzes the influence of political elites in the EU on the Europeans' understanding of climate change and on their behaviour relatively (Sohlberg, 2016). The research has shown that as the elite remain united in supporting the solutions for environmental problems, it strengthen the population's perception of the climate change threat in comparison with the countries where political elites are separated. This work has 
also demonstrated that this perception influence people's behaviour. Consequently, as the author concludes, the effect which political elites have on the public opinion on global climate change has been underestimated. K.S. Fielding and M.J. Hornsey try to explain cross-group clashes in the sphere of environmental problems through the theory of social identity (Fielding, Hornsey, 2016). Particularly, the authors consider how the social identity influences the attitude to the environment and propose their strategies to facilitate the environmental sustainability basing on the social identity.

Within the period of 2011-2013 scientific works in Russia mostly include the problems of climate change. In 2015 and 2016 such topics as international cooperation and development in Arctic gain the greatest attention. There almost no researches on the public opinion. The extreme climate areas attract much attention of not only the climate scientists, but also of those who are interested in the modern ethnic and cultural dynamics, including the ethnic groups of the Siberian Arctic. Starting form 2010, the group of scientists from Krasnoyarsk has been conducting the field research on the indigenous people of the North and Siberia, living in the Krasnoyarsk Territory in the Evenk, Taimyr Dolgano-Nenets and Turukhansk Districts (Avdeeva, Libakova, 2015; Amosov et al., 2012; Bukova, 2016; Kirko, Zakharova, 2013; Kirko, Keush, 2012; Kirko et al., 2013; Kirko, 2015; Kistova, Sevrughenko, 2016; Koptseva et al., 2011; Koptseva, Kirko, 2014a; Koptseva, Kirko, 2014b; Koptseva, Kirko, 2014c; Koptseva, 2015, Libakova, Sertakova, 2014; Pimenova, 2015; Reznikova, 2015b; Seredkina, 2014; Shyshatsky et al., 2012 and others). During the same period there are comparative researches on the indigenous people living in the extreme climate areas, i.e. in the Republic of Sakha (Yakutiya) and in the Krasnoyarsk Territory (Kirko, Nevzorov, 2015; Libakova et al., 2014a and others). These studies reveal modern processes peculiar to the indigenous people (Kistova et al., 2014; Libakova et al., 2014b; Reznikova et al., 2014 and others): their traditional economy, political processes, social and cultural projects and activities (Bralkova et al., 2015). It is the climate that determines such specific environmental ethics of the indigenous people of the North and Siberia, aspects of their education (Sitnikova, 2015), healthcare (Libakova, 2015), hygiene, artistic culture; it makes them take care of self-reproduction through the mother tongue preservation, use of ethnic symbols in applied arts and modern pictures.

In 2011-2013, the work by A.A. Alimov, L.N. Karlin, A.A. Muzalevskii, I.N. Samusevich, M.A. Gusakova includes a theoretical analysis of phenomena from the history of the Earth's climate to the future policy in the context of foreseeable climate changes (Alimov et al., 2011). The research describes possible solutions for the anthropogenic transformations of the climate through adapting small and indigenous peoples as the strategy of ecologically reasonable management in the Siberian conditions (Oparin et al., 2011). The problem of climate change is considered though the prism of international, interregional (Novikova, 2010) and diplomatic relations (Polyakova, 2010), international documents (Berdin et al., 2003), juridical aspect of the Kyoto Protocol (Pushkina, 2013). The authors theoretically analyze the Americans' opinion on the scientific information about the problem of global climate change (the experiment of 20032008). They prove that the scientific explanation is not always authoritative to the society; moreover, it can split the public opinion into two political poles: whether global warming has already impacted, whether it threatens the respondents' life or whether the problem of global warming has been exaggerated. The thesis that the science serves as a social communicator only within 
the straight address to people with a "party" consciousness has been supported (Khart, 2013). The short- and long-term forecasts for climate changes have been investigated and the notion of model climate has been given in (Nikitin, 2012). The resolutions of the United Nations Framework Convention on Climate Change, of the Conference on Environmental Problems in Rio de Janeiro, Kyoto and Copenhagen have been analyzed in (Mutagirov, 2010). The international relations in the global climate change solution have been discussed in (Slin'ko, 2011), as well as the global climate change impact on the global economy - in (Makarov, 2011).

The period of 2011-2012 is also marked by a number of researches containing the analysis of Arctic. Yu.F. Lukin in his article introduces a philosophical reflection on the environmental arctic phobia as a social phenomenon: environmental pollution, radiation phobia, emergencies, geophysical war, global warming, possible war with climatic weapons implementation in the sphere of artificial influence on the climate and weather (Lukin, 2012). D.S. Chumakov considers the need for energy development in Arctic and multilateral cooperation in the Arctic Council (Chumakov, 2011).

I.I. Avvakumov has taken a survey on the public opinion on climate change: in 2015 - among the students and the residents of the Republic of Sakha (Yakutia); the purpose of this research is to outline social aspects of global climate warming. The findings have demonstrated that the population notes climate change in summer and winter warming, shift in the seasons-change and temperature shocks.

The modern national researches are focused on climate change as the environmental problem and on its reasons (Kanilo, 2016), on the role of anthropogenic factor in global climate change (Alimov et al., 2016), consideration of the international resolutions on climate change (Problemy okruzhayuschei sredy, 2016) which prevent global environmental problems (Aleksandrova, 2016). The vectors of international exploration of the Arctic's ecology and natural resources are being intensively discussed (Koval', 2016). In recent years, there have been theoretical seminars and International Conferences on the problems of global economy with regard to climate change and its impact on globalization: limited natural resources, necessity of geoeconomic development of Arctic (IWEIR RAS, 2016; Peter the Great St. Petersburg Polytechnic University, 2016). The terminology for the sphere of migration ecology is also being drafted - such notions as "climate migrant", "environmental migrant" or "environmental refugee" have already been introduced (Lukyanets, 2015). For the first time there have been teaching materials written by the employees of the ministries of emergencies and disaster management; one of the parts describes the problem of human safety under global climate change (Vorobiev, 2011). The monograph "The Protection of Population and the Russian Federation Territory in the Context of Climate Change" contains large sections related to the problems of state policy, climate change's impacts on people and possible climate changes in the future (Akimov et al., 2016). A separate study reveals the regional reasons and anthropogenic effects on the nature in the Central Asian Territory which suffers from the Aral Sea disappearance (Khasanov, 2015).

\section{Conclusions}

The question of attitude to climate change emerged in the foreign science in the 1990s, though there was nothing of that kind in Russia.

The foreign researches of the 1970s-1980s deals with the multi-directed problems of climate change to identify the climate scenario and its development pattern both internationally and 
regionally. In the 1990 s the foreign scientists conducted their works on the attitude to climate change in German, the UK, Uruguay, the USA and other countries. These scientific works have a certain common ground - the researchers have tried to outline a general picture of climate change, information channels; the features of the attitude in particular social groups has usually been out of the focus. Nevertheless, there are first cross-cultural researches on the attitude to climate change aimed at analyzing the attitude to this problem in different societies.

In the beginning of the 2000s these crossdisciplinary studies of climate change continue, and in 2004 the scientists become interested in analyzing public opinions that allows indentifying vital problems for the population in the sense of climate change: low awareness in the questions of environmental safety, distrust of the environmental scientific explanations made in the mass media and marginal point in the process of social problems solution. The researchers develop particular recommendations for the authorities and multisectoral agencies.

In other countries the $2010 \mathrm{~s}$ meets a research boom which deal with the attitude to climate change. Moreover, these works are very specific and narrow judging by the subject, respondent selection and etc. The analysts cover the following territories: South Africa, the South Pacific Ocean Islands, the USA, Malta, China, Nepal, the Philippines, South America, Australia, the EU and Nigeria. The respondents are represented by the students and university faculty, farmers, nurses, school students and zoo visitors. Special attention is given to the farmers and teenagers (school children and students) since they will the first who feel climate changes stronger than the other social groups; besides the farming hugely enough influence the nature contributing to climate change. The teens represent a special group of respondents since when growing older they will have to cope with even more severe climate change; that is why it is necessary to assess and correct their thinking about this problem. In the 2010s the scientists address the issues on the degree of awareness on climate changes, the role of religion in it, the impact of particular emergencies linked to the atmospheric phenomena on the understanding of global climate change, the questions of more efficient channels of the information about global warming's reasons and consequences; people's adaptation to climate changes; the influence of political elites on the comprehension of climate change and etc.

The national researches of the 1950-1960s lack the attitude to climate change; the main publications are dedicated to the problems of geographical ecology in the context of agricultural development in the Soviet Union. In 1970-1980s the Soviet scientists work not under the attitude to climate change, but under the latter as such.

In the 1990s, there have been analytical studies of the current programs in climate as well as modelling of the global scenario for the biosphere changes in the future. The first all-unions survey also reveals the lack of environmental thinking among the Russians of that time.

The national scientific works of the 2000s consider the problem of climate change, but not of the attitude to it. A great part of them deals with the role of government and business in the fight against climate change and with a detailed analysis of the basic international decisions on the battle against global climate change.

In the 2010s, there are two topics clearly determined by the Russian scientific community: the development of international cooperation and geo-ecological exploration of the Arctic Area as the sphere of energy and ecology. There are annual International Conferences and seminars aimed at discussing 
these issues and, thus, at identifying the future perspectives in the world and regional economies development with regard to climate change; the basic terminological framework is also considered and, finally, the social need to build environmental thinking through new educational programs on the environment and climate is articulated.

The All-Russian Center for the Public Opinion Research.

\section{References}

Akimov, V., Durnev, R., Sokolov, Yu. (2016). Protection of the Population and Territories of the Russian Federation in the Context of Climate Change [All-Russian Scientific Research Institute for Civil Defense and Emergency Situations of the Ministry of Emergencies of Russia], 119-152.

Aleksandrova, M.A. (2016). Assessment of Natural Capital as a Way to Integrated Management of Nature Use, In Economics and Entrepreneurship, 10-3 (75-3), 1052-1056.

Alimov, A.A., Karlin, L.N., Muzalevsky, A.A., Samusevich, I.N., Gusakova, M.A. (2011). The Earth's Climate: Myths and Reality, In Life Safety (2), 1-24.

Amosov, A.E., Bahova, N.A., Bokova, V.I. (2012). Korennye malochislennye narody Severa $i$ Sibiri v usloviiakh global'nykh transformatsiy (na materiale Krasnoyarskogo kraia). Chast' 1. Kontseptual'nye i metodologicheskie osnovy issledovaniia. Etnokul'turnaia dinamika korennykh malochislennykh narodov Krasnoyarskogo kraia. [Small Indigenous Peoples of the North and Siberia in the Onctext of Global Transformations (on the Example of the Krasnoyarsk Territory). Part 1. Conceptual and Methodological Basis for the Research. Ethnocultural Dynamics of the Small Indigenous Peoples in the Krasnoyarsk Teritory]. Krasnoyarsk: Izdatel'stvo Sibirskogo federal'nogo universiteta.

Andersen, P.A., Lustig, M.W., Andersen, J.F. (1990). Changes in Latitude, Changes in Attitude: The Relationship Between Climate and Interpersonal Communication, In Predispositions Communication Quarterly, 38(4), 291-311.

Annenkov, V.V. (1996). Global Changes and Geography: From the Biosphere to the Noosphere, In Earth and the Universe, 6, 10-16.

Arler, F. (2006). Ethics of Large-Scale change, In Geografisk Tidsskrift, 106 (2), 131-144.

Avdeeva, Yu.N., Libakova, N.M. (2015). Mezhdunarodnye praktiki sotsiokul'turnogo proektirovaniia po otnosheniiu k korennym malochislennym narodam Severa, Sibiri i Dal'nego Vostoka [International Practices of Sociocultural Project Development in Relation to the Small Indigenous Peoples of the North, Siberia and Far East Regions], In Sotsiodinamika [Sociodynamics], 10, 10-38. Available at: URL: http://e-notabene.ru/pr/article_16430.html

Avvakumov, I.I. (2015). Climate Change for Everyday Life, In Economy and Society, 106-110.

Berdin, V. Kh., Vasiliev, S.V., Danilov-Danilyan, V.I., Kokorin, A.O., Kuraev, S.N. (2003). The Kyoto Protocol: Issues and Answers [brochure], Moscow.

Bord, R.J., Fisher, A., O’Connor, R.E. (1999). Public Perceptions of Global Warming: United States and International Perspectives, In Climate Research, 11(1), 75-84.

Bralkova A., Gerasimova A., Govorukhina Y., et al. (2015). New Art Critic on the Banks of the Yenisei. Krasnoyarsk.

Bukova, M.I. (2016). Osobennosti etnokul'turnogo samosoznaniia etnicheskoy gruppy chulymtsev, kompaktno prozhivaiuschikh na territorii derevni Pasechnoe Tiukhtetskogo raiona 
Krasnoyarskogo kraia (Tsentral'naia Sibir') [The Features of Ethnocultural Self-Consciousness in the Chulyms Ethnic Group compactly settled in Pasechnoe, Tiukhtenskiy District in the Krasnoyarsk Territory], In Sotsiodinamika [Sociodynamics]. Available at: http://e-notabene.ru/pr/article_18414.html

Canilo, P. (2016). Ice Ages and Gobal Warming, In Internal Combustion Engines, 2, 97-106.

Carlton, J.S., Mase, A.S., Knutson, C.L., Lemos, M.C., Haigh, T., Todey, D.P., Prokopy, L.S. (2016). The Effects of extreme Drought on Climate Change Beliefs, Risk Perceptions, and Adaptation Attitudes, In Climatic Change, 135(1), 211-226.

Chelovek i klimat. Interv'yu s akademikom G.S. Golitsynym [The Man and Climate. Interview with G.S. Golitsyn] (2006). In Ekologiya i zhizn' [Ecology and Life], 6, 10-16.

Chubukov, L.A., Shvareva, Yu.N. (1973). Klimat, fluktuatsiii trendy klimaticheskikhizmeneniynarusskoyravnine v XX vek [Climate, Fluctuations and Trends of Climate Change on the Russian Plain in the 20th Century], In Voprosy preobrazovaniya prirody russkoy ravniny [Questions of Transformation of the Nature of the Russian Plain], 15.

Chumakov, D.S. (2011). The Main Vectors of International Cooperation in the Arctic, In Bulletin of the Moscow University. Series 25: International Relations and World Politics, 2, 41-61.

Darier, E., Schule, R. (1999). "Think Globally, Act Locally"? Climate Change and Public Participation in Manchester and Frankfurt, In Local Environment, 4(3), 317-329.

Doctors, B.Z., Safronov, V.V. (1992). Level of Consciousness of Environmental Problems: Profiles of Public Opinion, In Sociological Research, 12, 51-58.

Dubovsky, S.V. (1998). A Guide to Global Modeling, In Social Sciences and the Present, 3, 161-171.

Eggers, M., Kayser, M., Isselstein, J. (2015). Grassland Farmers' Attitudes Toward Climate Change in the North German Plain, In Regional Environmental Change, 15(4), 607- 617.

Fenger, J., Buch, E., Jakobsen, P.R., Vestergaard, P. (2008). Danish Attitudes and Reactions to the Threat of Sea-level Rise, In Journal of Coastal Research, 24 (2), 394-402.

Fielding, K.Sh., Hornsey, M.J. (2016). A Social Identity Analysis of Climate Change and Environmental Attitudes and Behaviors: Insights and Opportunities, In Frontiers in Psychology, 7, 1-12.

Forbes, B.C., Stammler, F. (2009). Arctic Climate Change Discourse: The Contrasting Politics of Research Agendas in the West and Russia, In Polar Research, 28 (1), 28-42.

Galdies, C., Said, A., Camilleri, L., Caruana, M. (2016). Climate Change Trends in Malta and Related Beliefs, Concerns and Attitudes Toward Adaptation Among Gozitan Farmers, In European Journal of Agronomy, 74, 18-28.

González, L.E., Da Silveira, P. (1997). The People's Attitudes Towards Global Environmental Phenomena: a Case Study, In Climate Research, 9(1-2), 95-100.

Izrael', Yu.A., Nazarov, I.M., Gitarskiy, M.L., Nakhutin, A.I., Yakovlev, A.F. (2002). Kiotskiy protokol - problemy yego ratifikatsii [The Kyoto Protocol - the Problems of its Ratification], In Meteorologiya i gidrologiya [Meteorology and Hydrology], 11, 5-12.

Kagan, B.A., Ryabchenko, V.A., Safray, A.S. (1984). Reaktsiya sistemy okean-atmosfera na unichtozheniye lesa [Reaction of the Ocean-Atmosphere System to Forest Destruction], In Doklady Akademii nauk SSSR [Reports of the USSR Academy of Sciences], 278 (4-6), 979.

Kalinin, A.R., Korobova, O.S., Mikhina, T.V. (2007). Ekonomicheskiye osobennosti ustoychivogo razvitiya megapolisov v svete klimaticheskikh problem [Economic Features of Sustainable Development of Megacities in the Light of Climate Problems]. Moscow. 
Kattsov, V.M., Meleshko, V.P. (2008). Sovremennye prioritety fundamental'nykh issledovaniy klimata [Current Priorities of Fundamental Climate Researches], In Trudy Glavnoy geofizicheskoy observatorii im. A.I. Voyeykova [Proceedings of the Main Geophysical Observatory named after A.I. Voieikov], 557, 3-19.

Khasanov, A.Kh. (2015). The Concept of Global Warming and the Ecological and Climatic Anomalies of Central Asia, In Bulletin of the Tajik National University. Series of Natural Sciences, 1 (3), 282-288.

Kheyfets, M.N. (1979). K probleme kolebaniya urovnia ozera Issyk-Kul' v svete sovremennykh izmeneniy klimata [On the Problem of Fluctuations in the Level of Lake Issyk-Kul in the Light of Current Climate Changes], In Pribrezhnaya zona ozera Issyk-Kul' [The Coastal Zone of Lake IssykKul]. Frunze, 131-137.

Kirko, V.I., Zakharova, K.N. (2013). Traditsionnaia khoziaistvennaia deiatel'nost' etnosokhraniaiuschii obraz zhizni [Traditional Economy as the Ethnosaving Lifestyle], In Arktika i Sever [Arctic and the North], 12, 24-31.

Kirko, V.I., Nevzorov, V.N. (2015). Innovatsionnye protsessy v Sibirskoi Arktike [Innovative Processes in the Siberian Arctic], In Sotsiodinamika [Sociodynamics], 5, 70-82. Available at: http://enotabene.ru/pr/article_15325.html

Kirko, V.I., Keush, A.V. (2012). Vovlechenie korennykh malochislennykh narodov Severa v innovatsionnye protsessy [Involvement of the Small Indigenous Peoples of the North into Innovative Processes], In Vestnik Krasnoyarskogo gosudarstvennogo agrarnogo universiteta [Bulletin of Krasnoyarsk State Agrarian University], 10, 233-237.

Kirko, V.I., Bukharov, A.V., Keush, A.V. (2010). Otsenka innovatsionnogo potentsiala tipovykh territorial'no-administrativnykh obrazovanii Krasnoyarskogo Kraia [The Assessment of Innovative Capacity for Typical Territorial Units in the Krasnoyarsk Territory], In Innovatsii [Innovations], 12, 78-83.

Kirko, V.I., Koptseva, N.P., Nevzorov, V.N., Nozdrenko, E.A., Slabukha, A.V. (2013). Mezhdistsiplinarnye ekspeditsii - effektivniy sposob formirovaniia comand dlia realizatsii kompleksnykh innovatsionnykh i investitsionnykh proektov [Crossdisciplinary Expeditions as Effective Way to Form the Teams on Integrated Innovative and Investment Projects Implementation], In Arktika i Sever [Arctic and the North], 13, 4-13.

Kirko, V.I. (2015). Postsovetskie praktiki sokhraneniia etnokul'turnoy identichnosti korennykh narodov Severa i Sibiri v Krasnoyarskom krae Rossiiskoy Federatsii [The Post Soviet Experience on the Ethnocultural Identity Perservation for the Small Peoples of the North and Siberia in the Krasnoyarsk Territory of the Russian Federation], In Sotsiodinamika [Sociodynamics], 6, 113-133. Available at: http://e-notabene.ru/pr/article_15607.html

Kistova, A.V., Sevruzhenko, N.S. (2016). Koreitsy v sovremennoi Rossii: rol' etnicheskikh men'shinstv [The Koreans in the Modern Russia: the Role of Ethnic Minorities], In Sotsiodinamika [Sociodynamics], 3, 62-72. Available at: http://e-notabene.ru/pr/article_18204.html

Kistova, A.V., Pimenova, N.N., Zamaraeva, Ju.S., Reznikova, K.V. (2014). Research Possibilities for Studying the Indicators of Quality of Life of Indigenous Peoples of the North (based on the study of indigenous peoples of the North of Russia), In Life Sci J, 11(6), 593-600.

Koptseva, N. (2015). The Current Economic Situation in Taymyr (the Siberian Arctic) and the Prospects of Indigenous Peoples' Traditional Economy, In Economic Annals-XXI, 9-10, 95-97. 
Koptseva, N.P., Sertakova, E.A., Il’beikina, M.I., Zamaraeva, Iu.S., Libakova, N.M., Bakhova, N.A., Luzan, V.S., Reznikova, K.V., Kistova, A.V., Pimenova, N.N., Nevol'ko, N.N. (2011). Kul'tura korennykh i malochislennykh narodov severa $v$ usloviiakh global'nykh transformatsii [The Culture of Small Indigenous Peoples of the North in the Context of Global Transformations]. Sankt-Petersburg.

Koptseva, N.P., Kirko, V.I. (2014a). Specificity of Ethnogeny Indigenous Peoples by Central Siberia in the Transition from the Traditional Type of Society to Modern Society, In Life Sci J, 11(7), 409-413.

Koptseva, N.P., Kirko, V.I. (2014b). Modern Specificity of Legal Regulation of Cultural Development of the Indigenous Peoples of the Arctic Siberia under the Global Transformations, In Life SciJ, 11(9), 314-319.

Koptseva, N.P., Kirko V.I. (2014c). Processes of Acculturation Khakases (Indigenous People Of Southern Siberia), Living Outside the Khakassia in the Urban and Student Environment, In American Journal of Applied Sciences, 11 (12), 1269-1275.

Koval', V.P., Lyzhin, D.N. (2016). International Environmental Cooperation in the Arctic, In Arctic and the North, 22, 139-149.

Kuvshinova, K.V. (1987). Tsirkulyatsionnye mekhanizmy sovremennykh kolebaniy klimata [Circulation Mechanisms of Modern Climate Variations]. Moscow.

Larin, V. (2005). Ob izmenenii klimata, Kiotskom protokole, energeticheskom budushchem mira i Rossii [On Climate Change, the Kyoto Protocol, the Energy Future of the World and Russia], In Energiya: ekonomika, tekhnika, ekologiya [Energy: Economics, Technology, Ecology], 5, 42-47.

Libakova, N.M., Sitnikova, A.A., Sertakova, E.A., Kolesnik, M.A., Ilbeikina, M.I. (2014a). Interaction of the Yakut Ethnicity and Biological Systems in the Territory of the Sakha Republic (Hordogoy Settlement, Suntarsky District) and Krasnoyarsk Krai (Essey Settlement, Evenks District), In Life Sci J, 11(6), 585-592.

Libakova, N.M., Sitnikova, A.A., Sertakova, E.A., Kolesnik, M.A., Ilbeikina, M.I. (2014b). Modern Practices of Regional and Ethnic Identity of the Yakuts (North Asia, Russia), In Life Sci J 11(12), 133-140.

Libakova, N.M. (2015). Upravlenie zdravoohraneniem dlia korennykh narodov Tsentral'noi Sibiri (na materiale analiza Krasnoyarskogo Kraia) [The Healthcare Management for the Indigenous Peoples of the Central Siberia (on the Analysis of the Krasnoyarsk Territory], In Trendy i Upravleniie [Trends and Management], 4, 380 - 394.

Libakova, N.M., Sertakova, E.A. (2014). Kul'turologicheskoe issledovanie korennykh malochislennykh narodov Severa Krasnoyarskogo kraia: rezul'taty ekspertnogo interv'iu [Culturological Research on the Small indgenous Peoples of the North of the Krasnoyarsk Territory: the Expert Interview Proceedings], In Sovremenniye problemy nauki i obrazovaniia [Modern Problem of Science and Education], 4.

Liverman, D.M., Merideth, R. (2002). Climate and Society in the US Southwest: The Context for a Regional Assessment, In Climate Research, 21 (3), 199-218.

Lorenzoni, I., Pidgeon, N.F. (2006). Public Views on Climate Change: European and USA Perspectives, In Climatic Change, 77 (1-2), 73-95.

Luebke, J.F., Clayton, S., Kelly, L.-A. De G., Grajal, A. (2015), Global Climate Change Attitudes and Perceptions among South American Zoo Visitors, In Zoo Biology, 34(4), 393-402. 
Lukin, Yu.F. (2012). Arctic Social Phobias, In Arctic and north, 5, 31-61.

Lukyanets, A., Pismennaya, A., Karabulatova, I., Riazentsev, S., Manshin R. (2015). Climate Change as a Factor in the Transformation of Geopolitical Relations: the Specifics of Migration from Vietnam to Russia, In Socio-Economic and Humanitarian-Philosophical Problems Modern Science, 111-115.

Makarov, I.A. (2011). Global Climate Change and the World Economy, In World Economy and International Relations, 12, 3-12.

Malyarenko, Yu.Ye., Bykov, A.T., Malyarenko, T.N., Kurbatova, E.V., Zaika, V.G. (2009). Klimat i zdorov'ye cheloveka. Soobshcheniye 3. Zavisimost' funktsional'nogo sostoyaniya organizma ot temperaturnogo faktora i geomagnitnykh vozmushcheniy [Climate and Human Health. Message 3. The Dependence of Functional State of the Organism on the Temperature Factor and Geomagnetic Disturbances], In Valeologiya [Valeology], 1, 7-18.

Matarzin, Y.U., Danilova, M.M., Lyutin, A.A. (1970). Vliyaniye Kamskogo vodokhranilishcha na prirodu prilegayushchey territorii [Influence of the Kama Reservoir on the Nature of the Adjacent Territory].

Messerli, B., Grosjean, M., Hofer, T., Núñez, L., Pfister, C. (2000). From Nature-Dominated to Human-Dominated Environmental Changes, In Quaternary Science Reviews, 19 (1-5), 459-479.

Mohanraj, K., Karthikeyan, C. (2016). Assessing Attitude of Tank Irrigated Farmers Towards Climate Change, In Journal of Extension Education, 26(4), 5369-5371.

Morrison, M., Duncan, R., Parton, K. (2015). Religion Does Matter for Climate Change Attitudes and Behavior, In PLoS ONE, 10(8), 1-16.

Moser, S.C., Luers, A.L. (2007). Managing Climate Risks in California: the Need to Engage Resource Managers for Successful Adaptation to Change, In Climatic Change, 87 (1 SUPPL), 309-322.

Moyano, E., Paniagua, A., Lafuente, R. (2009). Environmental Policy, Climate Change and Public Opinion: the Case of Andalusia, In Revista International de Sociologia, 3, 681-699.

Mutagirov, D.Z. (2010). Human Rights to Clean Air, Water and Food through the Prism of the Kyoto Protocol and the Copenhagen Accord, In Political Expertise: POLITEX, 6 (1), 255-273.

Myagkov, S.M. (1981). Vozmozhnie izmeneniya prirody Tsentral'nogo Tyan'-Shanya k 2025 godu [Possible Changes in the Nature of the Central Tien Shan by 2025], In Vestnik MGU. Seriia: Geografiya [Bulletin of the Moscow State University. Series: Geography], 5, 28.

National Research Council, Division of Behavioral and Social Sciences and Education, Committee on the Human Dimensions of Global Change, Panel on Strategies and Methods for Climate-Related Decision Support (2009). In Informing Decisions in a Changing Climate, 1-188.

Nikitin, M.A. (2012). Potential Predictability of the Climate in the Scales of Decades According to the Climate Model of the IVM RAN (2012), In Solar Activity and the Nature of Global and Regional Climate Change, 46-47.

Novikova, L. Yu. (2010). Climate Change as a Factor in the Development of Interregional Relations, In Integration of the Economy into the System of World Economic Relations. Proceedings of the XV International Scientific and Practical Conference, 240-242.

Nunn, P.D., Mulgrew, K., Scott-Parker, B., Hine, D.W., Marks, A.D.G., Mahar, D., Maebuta, J. (2016). Spirituality and Attitudes Towards Nature in the Pacific Islands: Insights for Enabling ClimateChange Adaptation, In Climatic Change, 136 (3-4), 477-493. 
Ofoegbu, C., Chirwa, P.W., Francis, J., Babalola, F.D. (2016). Conceptualising Climate Change in Forest-Based Rural Areas of South Africa: Community Perceptions and Attitudes, In International Forestry Review, 18(3), 319-333.

Ojomo, E., Elliott, M., Amjad, U., Bartram, J. (2015). Climate Change Preparedness: a Knowledge and Attitudes Study in Southern Nigeria, In Environments, 2(4), 435-448.

On the Issue of Ecological Modernization as a Model of Sustainable Development (2016). Modern development problems. Proceedings of the Theoretical Seminar at IMEMO RAN [National Research Institute of World Economy and International Relations named after E.M. Primakov Institute of the Russian Academy of Sciences], 95-79.

Oparin, R.V., Kulikova, N.A., Shchigreva, S.N. (2011). Traditional and Non-Traditional Ways of Adapting the Indigenous Peoples of Siberia to Climate Change, In The world of Science, Culture, Education, 6-2, 440-441.

Paris 2015: Reaching a Global Agreement on Climate Change (2016). In Problems of the Environment and Natural Resources, 4, 19-36.

Pimenova, N.N. (2015). Korennye malochislennye narody v sovremennoj situacii: ob'em i soderzhanie poniatiia [The Small Indigenous Peoples in the Modern Context: the Volume and Content of the Notion], In Sotsiodinamika [Sociodynamics], 1, 112-134.

Plotnikoff, R.C., Wright, M.F., Karunamuni, N. (2004). Knowledge, Attitudes and Behaviours related to Climate Change in Alberta, Canada: Implications for Public Health Policy and Practice, In International Journal of Environmental Health Research, 3, 223-229.

Polyakova, E. (2010). Climatic Diplomacy and Global Climate Change Problems, In Diplomatic Service, 55-61.

Poudet, D.D., Duex, T.W. (2017). Vanishing Springs in Nepalese Mountains: Assessment of Water Sources, Farmers' Perceptions, and Climate Change Adaptation, In Mountain Research and Development, 37(1), 35-46.

Processes of the Global Economy (2016). In Collection of Proceedings of the International Scientific and Practical Conference St. Petersburg Polytechnic University of Peter the Great.

Prudente, M.S., Anito, J.C., Aguja, S.E. (2015). Exploring Climate Change Conceptions and Attitudes: Drawing Implications for a Framework on Environmental Literacy, In Advanced Science Letters, 21(7), 2413-2418.

Pushkina, E.G. (2013). Perspectives of Anthropogenic Climate Change, In Priority Research Areas: from Theory to Practice, 8, 29-34.

Ranney, M.A., Clark, D. (2016). Climate Change Conceptual Change: Scientific Information Can Transform Attitudes, In Topics in Cognitive Science, 8(1), 49-75.

Rebich-Hespanha, S., Rice, R.E. (2016). Dominant Visual Frames in Climate Change News Stories: Implications for Formative Evaluation in Climate Change Campaigns, In International Journal of Communication (Online), 4830-4862.

Reusswig, F. (2010). Sustainability Transitions through the Lens of Lifestyle Dynamics, In Sustainable Production Consumption Systems: Knowledge, Engagement and Practice, 39-59.

Reznikova, K.V. (2015b). Etnichnost' kak kategoriia sotsial'nogo poznaniia [Ethnicity as a Category of Social Cognition], In Sotsiodinamika [Sociodynamics], 1, 101-111. Available at: http://enotabene.ru/pr/article_14228.html 
Reznikova, K.V., Zamaraeva, J.S., Kistova, A.V., Pimenova, N.N. (2014). The Current State of Traditional Socio-Cultural Practices of Indigenous Peoples of the North (on the Example of Cultures of Selkups, Nenets and Essey Yakuts), In Life SciJ, 11(12), 126-132.

Rogozhina, N. (2016). Modern Problems of Development, In Materials of the Theoretical Seminar at IMEMO RAN, 1 (2), 70-75.

Seredkina, N.N. (2014). Etnicheskaia kartina mira v kontekste sovremennykh sotsial'nykh issledovanii [The Ethnic Worldview in the Context of Modern Social Researches], In Sotsiodinamika [Sociodynamics], 10, 26-59. Available at: http://e-notabene.ru/pr/article_13441.html

Shisanya, C.A., Khayesi, M. (2007). How is Climate Change Perceived in Relation to Other Socioeconomic and Environmental Threats in Nairobi, Kenya? In Climatic Change, 85 (3-4), 271-284.

Shishatskiy, N.G., Kirko, V.I., Keush, A.V. (2012). Sotsial'no-ekonomicheskie problemy sozdaniia territorii tradicionnogo prirodopol'zovaniia [Social and Economic Problems in Creation of the Territories with Traditional Resource Management], In Arktika i Sever [Arctic and the North], 7, 178-184.

Shwom, R., Dan, A., Dietz, T. (2008). The Effects of Information and State of Residence on Climate Change Policy Preferences, In Climatic Change, 90 (4), 343-358.

Sitnikova, A.A. (2015). Indigenous Education: Actual Status and Problems. In Pedagogy and Education, 3, 300-311.

Slinko, A.A. (2011). Global Climate Change and Modern International Relations, In Transformations of Political Systems in the Context of Global Development Trends. Collection of Scientific Articles. Voronezh, 5-7.

Smirnov, B.M. (1975). Ekologicheskiye problemy atmosfery Zemli [Environmental Problems of the Earth's Atmosphere], In Uspekhi fizicheskikh nauk [Progress in Physical Sciences], 117(10), 313332.

Sohlberg J. (2016). The Effect of Elite Polarization: A Comparative Perspective on How Party Elites Influence Attitudes and Behavior on Climate Change in the European Union, In Sustainability, $9(1), 39$.

Steg, L., Vlek, C. (2009). Social Science and Environmental Behavior, In Principles of Environmental Sciences, 97-141.

Stenchikov, G.L., Stepanov, D.S. (1989). Modelirovaniye klimaticheskikh protsessov [Modeling of Climatic Processes], In Matematicheskoye modelirovaniye. Metody opisaniya i issledovaniya slozhnykh sistem [Mathematical Modeling. Methods for Describing and Researching Complex Systems]. Moscow.

Stenhouse, N., Harper, A., Cai, X., Cobb, S., Nicotera, A., Maibach, E. (2017). Conflict about Climate Change at the American Meteorological Society: Meteorologists' Views on a Scientific and Organizational Controversy, In Bulletin of the American Meteorological Society, 98(2), 219-227.

Tsalikov, R.Kh.(2009). Izmeneniya klimata na severe Rossii: opasnosti i ugrozy zhiznedeyatel'nosti [Climate Change in the North of Russia: Dangers and Threats to Life], In Region: Ekonomika i Sotsiologiya [Region: Economics and Sociology], 1, 158-166.

Vasilieva, N.A. (2009). Noosferniy variant tsivilizatsionnykh perspektiv chelovechestva [Noosphere Variant of Civilization Prospects of Mankind], In Politicheskaya ekspertiza: POLITEKS [Political expertise: POLITEX], 5(4), 170-179. 
Vendrov, S.L., D’yakonov, K.N., Reteyum, A. Yu. (1970). Vliyaniye vodoyemov na klimat poberezhiy v razlichnykh geograficheskikh zonakh [Influence of Water Bodies on the Climate of Coasts in Various Geographical Zones], In Vliyaniye vodokhranilishch lesnoy zony na prilegayushchiye territorii [Influence of Reservoirs of the Forest zone on Adjacent Territories], 6-12.

Vorobiev, Yu., Akimov, V., Sokolov, Yu. (2011). Comprehensive Human Security. Moscow.

Vorontsov, P.A., Khayrullin, K.Sh. (1977). Vozdeystviye bol'shogo goroda na klimat v raznykh masshtabakh [The Influence of a Large City on the Climate in Different Scales], In Trudy GGO [Proceedings of the State Pedagogical University], 391, 107-112.

Weart, S.R. (2010). The Idea of Anthropogenic Global Climate Change in the 20th Century, In Wiley Interdisciplinary Reviews: Climate Change, 1 (1), 67-81.

Westra, L. (1996) Environmental Integrity, Racism, Health, In The Science Of The Total Environment, 184 (1-2), 57-66.

Whitmarsh, L., Köhler, J. (2010). Climate Change and Cars in the EU: the Roles of Auto Firms, Consumers, and Policy in Responding to Global Environmental Change, In Cambridge J Regions Econ Soc, 3 (3), 427-441.

Williamson, T.B., Watson, D.O.T. (2010). Assessment of Community Preference Rankings of Potential Environmental Effects of Climate Change Using the Method of Paired Comparisons, In Climatic Change, 99 (3), 589-612.

Wilson, R. (2000). Some Global Environmental Issues of Public Concern [23rd International Conference on Global Warming and Energy Policy], In Lauderdale [Global warming and energy policy], 11-28.

Xiao, J., Fan, W., Deng, Y., Li, S., Yan, P. (2016). Nurses’ Knowledge and Attitudes Regarding Potential Impacts of Climate Change on Public Health in Central of China, In International Journal of Nursing Sciences, 3(2), 158-161.

Zalikhanov, M.Ch. (2003). Itogi parlamentskoy chasti Rio+10 [Results of the Parliamentary Part of Rio + 10], In Ustoychivoye razvitiye. Nauka i praktika [Sustainable Development. Science and Practice], 1, 47-51.

\title{
Историографический обзор
}

\section{научных исследований по проблеме \\ отношения населения к изменениям климата}

\author{
К.В. Резникова, Ю.С. Замараева \\ Сибирский федеральньій университет \\ Россия, 660041, Красноярск, пр. Свободньй, 79
}

Тема отношения населения к изменению климата весьма молодая, возникиая только во второй половине ХХ в. Она была поднята в зарубежной науке в 1990-х г2., отечественные ученые до сих пор не уделяют этому направлению должного внимания. В 1990-х г2. зарубежные исследователи проводили изучение отночения к изменению климата в Германии, Великобритании, Уругвае, США и других странах. Научные работы этого периода обладают достаточно об- 
щчим характером. В 2010-х г2. за рубежом отмечается бум исследований, посвященных отноиению к изменению климата; причем исследования носят очень специфичный, узкий характер, что проявлено в выборе предмета изучения, респондентов и др.

Ключевые слова: глобальное изменение климата, отношение населения, историография изучения климата.

Исследование выполнено при финансовой поддержке Российского фонда фундаментальных исследований, Правительства Красноярского края, Красноярского краевого фонда поддержки научной и научно-технической деятельности в рамках научного проекта № 17-16-24601.

Научная специиальность: 24.00.00 - культурология. 